\title{
Detection of water quality in crayfish ponds with IoT
}

\author{
Abdurrasyid, Indrianto, Meilia Nur Indah Susanti, Yudhi S. Purwanto \\ Department of Informatics, Institute of Technology PLN, Jakarta, Indonesia
}

\begin{tabular}{l} 
Article Info \\
\hline Article history: \\
Received Sep 11, 2020 \\
Revised Nov 17, 2020 \\
Accepted Dec 3, 2020 \\
\hline Keywords: \\
Crayfish pond \\
Crayfish pond sensor \\
Internet of thing \\
Perceptron method \\
Water quality
\end{tabular}

\begin{abstract}
Data from the Central Bureau of Statistics shows that during the first quarter of 2014 to 2019, the tendency of Indonesian crayfish export increases by an average of $3.54 \%$ in 2019 and reach 7.09 million USD. This number still fails to meet the global market demand caused by poor water quality due to cultivators' lack of experience and education. Two parameters measured in water quality are temperature and $\mathrm{pH}$. Thus, a device was made using IoT to maintain those conditions in order to increase the viability of the crayfish in the pond. The perceptron method is used to classify water quality based on those parameters. To send the data, ESP8266 is used as an intermediary for Arduino and cloud server. The result is that the information about the ponds' condition can be seen via a smartphone. The method gives a value of $98.06 \%$ accurate in determining water quality.
\end{abstract}

This is an open access article under the CC BY-SA license.

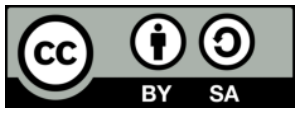

Corresponding Author:

Abdurrasyid Abdurrasyid

Department of Informatics, Institute of Technology PLN

Menara PLN, JL Lingkar Luar Barat Duri Kosambi, Cengkareng, Jakarta Barat, 11750, Indonesia

Email: arasyid@itpln.ac.id

\section{INTRODUCTION}

Crayfish is a fishery commodity that has an economic value and is already cultivated by the community. Besides having a high protein content, crayfish is also easy to cultivate. Crayfish is one of Indonesia's export commodities which has a tendency to increase from the first quarter of 2014 to 2019 with an average increase of $3.54 \%$ in 2019 reaching 7.09 million USD [1]. Up until now, there are more than 540 types of crayfish in the world and the number will keep rising as time goes by [2], Advantage of crayfish is that from its character, which is not stressed easily except for those on the dark places [3] and its immunity to disease as long as the needs of food, water quality, temperature and oxygen requirements are met, the craysfish can grow and develop quickly, and also has a high capability to lay eggs $[4,5]$. Crayfish cultivation can be a community business opportunity that can be done as an effort to improve home industry and community income. The community can make their own mini-ponds at home by using an aquarium or existing vacant spaces. The demand for crayfish is very high throughout the world and Indonesia has become the main global exporter of crayfish. One of the countries that imports crayfish from Indonesia is Czech Republic where this country was actually imports from various countries but starting in 2007, Indonesia has become the leader in importing crayfish where more than $80 \%$ of ornamental crayfish are imported from [6], not quite different with the Czech Republic, New Guinea also makes Indonesia as one of their main crayfish inportir [7]. This can be a starting point for the people to start crayfish cultivation business to fulfil the market demand or just for personal consumption. Water has an important role in this business because crayfish lives, grows and develops in the water. Good quality water will make them grow and develop well. Crayfish is best at the temperature of $21^{\circ} \mathrm{C}-25^{\circ} \mathrm{C}$ [8] but for the species from the tropical regions, the optimum temperature for growth is $24-30^{\circ} \mathrm{C}$ [9] although it still depends on its location. Most of the redclaw crayfish population can survive at $21-30^{\circ} \mathrm{C}$ [10], with dissolved oxygen $5.60 \pm 0.9 \mathrm{mg} / \mathrm{L}$, and $\mathrm{pH}$ of $7.12 \pm$ 
0.21 [8]. Water quality must always be checked to ensure that no unwanted materials that exceeds the crayfish tolerance threshold. Declining water quality can be caused by several factors such as water sources, the influence of weather, settling crayfish lobes and others. Conventional methods can cause the growth of crayfish to be disrupted, thus a crayfish cultivator must be diligent in caring them to produce a good quality crayfish. An unusual monitoring to the water quality will cause the loss of the crayfish business.

In this study the water quality parameters to be examined are temperature and $\mathrm{pH}$. Temperature determines the degree of cold or hot water which influences the growth and survival of the crayfish. This is proven by research [11] where the temperature difference in crayfish maintenance influences the daily growth rate and survival rate of red claw crayfish seeds. The daily growth rate and survival of red claw crayfish seeds reached optimum at between $25-28.20^{\circ} \mathrm{C}$ with a daily growth rate of $1.05 \%$ and survival rate of $85.93 \%$. Whereas when the temperature is higher $\left(32^{\circ} \mathrm{C}\right)$, the value of the daily growth rate and survival drops to $0.79 \%$ and $63.33 \%$. Low temperatures can cause the lobster to become inactive and reduce its appetite. In addition, low temperatures cause degeneration of red blood cells so that the process of respiration is disrupted. Conversely, if the temperature is higher, it will cause the crayfish's metabolic rate to accelerate so that the energy in the crayfish is used up for the metabolic process. Besides temperature, $\mathrm{pH}$ parameter also influences the growth and survival of the crayfish [12]. And the results of growth and best survival were obtained between $\mathrm{pH} 7-8$ whereas with $\mathrm{pH} 7$ and $\mathrm{pH}$ 8, the growth rate of the crayfish is low with a value of 0.02 gr. Inappropriate $\mathrm{pH}$ can affect the toxicity of other substances or chemicals. In addition, changes in $\mathrm{pH}$ can also cause the crayfish to experience stress [9].

Embedded system becomes an inseparable part of IoT, embedded systems can be enjoyed either by normal humans or who have deficiencies such as visual ability [13], for that embedded system knowledge must be an inseparable part in the activities of education in higher education [14], there have been many studies conducted by researchers in the field of IoT both in the field of Education, smart taxi in smart city [15], smart traffic lights that can help to reduce vehicles congestion on traffic lights [16]. In accordance with that matter, the researchers have used IoT in the field of agriculture and aquaculture. The research that was done by Lukito is using Io $\mathrm{T}$ to monitor the $\mathrm{pH}$ and temperature levels from the air which will be given to the hidroponic plants. The weakness of this research is that there is no action done when the water condition has a high or low $\mathrm{pH}$ and temperature levels [17], A similar research was done by Odey, conducted in 2013. The research conducted design and implementation of smart wireless mesh sensor networks for aquaculture, the drawback is because it is used only lightweight wireless, it cannot be controlled remotely and only reads input from sensors without any action done [18]. Another study was conducted by Chen in 2015 using GPRS Technology and MSP430f149 microprocessor to detect water quality using water level parameters, PH, temperature and oxygen levels, but the shortcomings of this study was that it only provide action to replace water and the technology used, and does not use the Internet, even though it is mobile based app [19]. The next research was done by Kilic where the water quality was measured using pictures from cellphone. This method still has a weakness where the person still has to come to the pond and will also create some difficulties for the crayfish farmers [20]. The research carried out only wireless sensor networks design to monitor $\mathrm{pH}$ levels and temperatures without any action done when $\mathrm{PH}$ levels or temperature rises and falls [21], From all of the research that has been done before, aside from only reading input from censors, the lack of incorporating scientific methods used to measure water conditions, which become one of the factors affecting the efficiency of crayfish growth is experience and Education which should be developed with IoT in aquaculture.

The method used in this case is the perceptron method. Perceptron is a simple method of artificial neural networks. Perceptron is used to classify a type of pattern that is often known as linear separation. In this study, research that used perceptron method was conducted in 2012 which in this research, they only use one parameter (TDS) without involving $\mathrm{pH}$ and temperature that are essential in crayfish cultivation [22]. Also, in 2014 the perceptron method was also used to measure water quality using 3 parameters, i.e. $\mathrm{pH}$, TDS and SAR, without involving temperature that actually becomes one of the most important things in crayfish cultivation.Here, there was no action done if they found a bad number on the water quality [23]. The next research was done in 2019 to measure water quality but was not used in measuring pond water quality. This research shows that perceptron method is good to measure water quality [24]. From the literature study of the researches that has been done above, it can be concluded that this study has novelty in terms of the use of IoT Technology in crayfish aquaculture by using the perceptron method in determining pond water quality.

\section{RESEARCH METHOD}

This study uses stages of the prototyping method that is well used to provide users with an understanding of how data travels through the system and solve problems between users and analysts which might be arising from the inability of the user to clearly define their needs [25]. This study will go through 
five stages: First, analysis of the system running in which from the results of the observations made that the temperature and $\mathrm{pH}$ checking of the water on the pond was still done manually by the crayfish cultivator. Temperature checking was done by inserting a thermometer into the aquarium and looking at the value of the temperature produced, and measuring $\mathrm{pH}$ was done using a $\mathrm{pH}$ meter dipped in water. From the interviews conducted, too low temperature can cause the egg hatching process to be long. At normal temperature, egg hatching takes around five weeks, whereas if temperatures are low, hatching can take seven to eight weeks. In addition, low temperatures cause crayfish activity to idle so that the appetite is not too large. This results in slow growth on the cryfish development. The $\mathrm{pH}$ itself also affects crayfish growth and their survival effort. In maintaining the crayfish, the value of temperature and $\mathrm{pH}$ are maintained in the range of $24^{\circ} \mathrm{C}-30^{\circ} \mathrm{C}$ and 6-8 $\mathrm{pH}$ so that the condition of the pond remains good.

Second, the analysis of the proposed system. From the results of the problem analysis it can be seen when the user wants to see the temperature and $\mathrm{pH}$ value in the pond, the user does not need to come directly to the crayfish pond. The value of temperature and $\mathrm{pH}$ in the pond can be directly monitored through the application in the smartphone. In addition to temperature control, if the water temperature is detected less than $27^{\circ} \mathrm{C}$, the heater will automatically turn on. If the temperature has returned to its normal temperature, the heater will automatically turn off. Similar with water conditions, if the water conditions are bad then the water pump will automatically work to replace the water in the crayfish pond. Determination of water conditions is determined by using the perceptron method to classify good or poor water conditions. Users can also control the heater and water change manually through the application on the smartphone. Temperature and water control are carried out so that the temperature remains in the optimal temperature and $\mathrm{pH}$ conditions, i.e. $25^{\circ} \mathrm{C}-29^{\circ} \mathrm{C}$ and $6-8 \mathrm{pH}$ so that it can increase the survival of the crayfish.

Figure 1 shows the tool scheme and how the data is sent from a sensor until it can be read on the mobile phone, especially on the android devices, where the data from the sensor is sent through an Arduino board then the internet connection will be read by wifimodule ESP8266 and sent to cloud, which on this research, uses thingspeak server, and finally sent to the mobile device, vice versa.

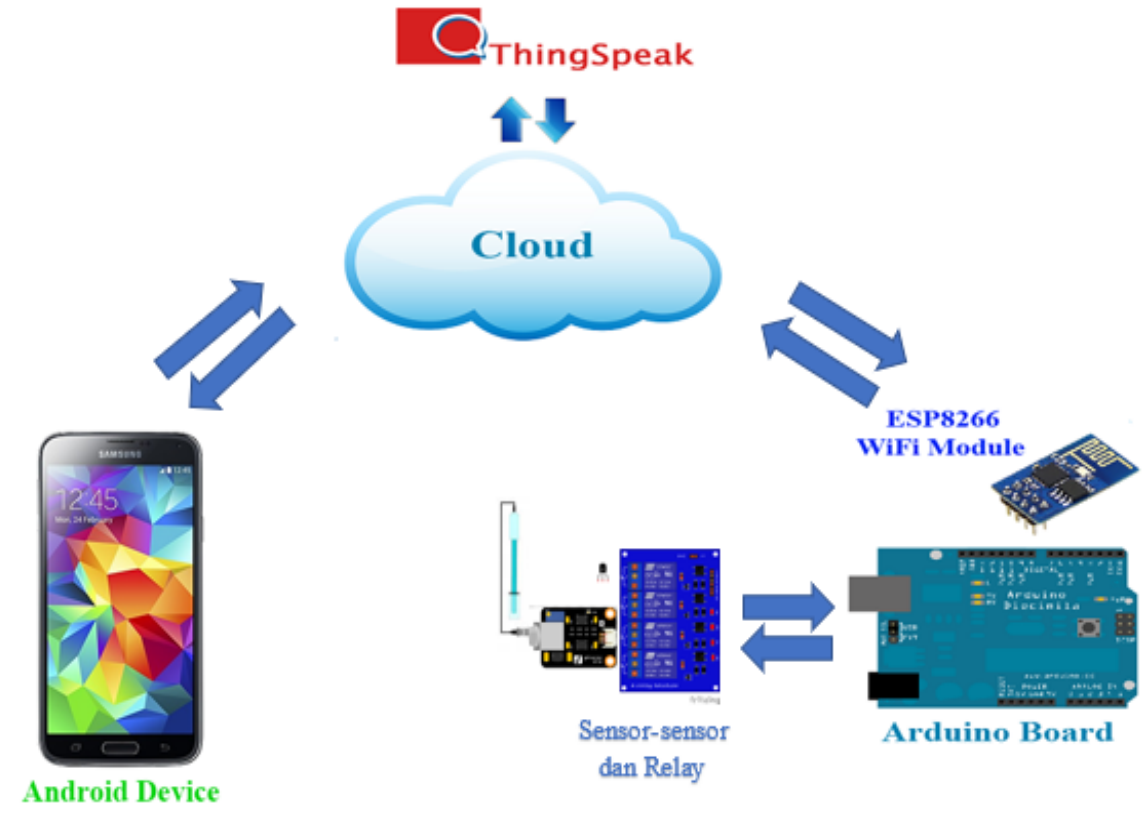

Figure 1. Tool schema and data delivery

Third, hardware designs. At this stage, the hardware needed are Arduino Uno, ES8266 module, temperature sensor (DS16B20), $\mathrm{pH}$ sensor, ultrasonic sensor, 4 channel relay, breadboard, water pump, Heater, the use of ultrasonic sensors which are commonly used to measure distances and Arduino as a data processor, where it was also used to help the blind in walking [13]. The design of the device starts with making a diagram block like Figure 2. 


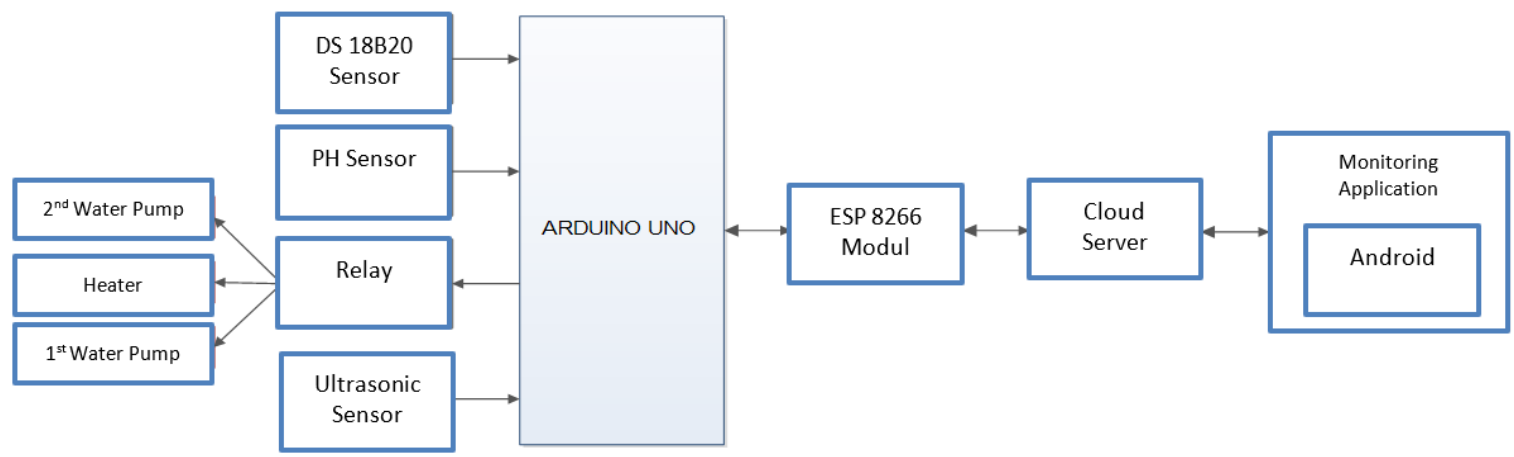

Figure 2. Design of the device block digram

DS18B20 sensor is an input used to read water temperature, while $\mathrm{pH}$ sensor is an input used to read water $\mathrm{pH}$ level. Arduino uno is used to control the running of all components connected to Arduino Uno. ESP8266 Module is a device that mediates between Arduino and cloud servers in the process sending and receiving data. Android is used as a client to monitor or control crayfish ponds. Relays function as switches to control devices such as water pumps and heaters based on orders from Arduino Uno. Ultrasonic sensors function to measure the distance from an object. These devices are used to measure water levels, while the design results can be seen in the series can be seen in Figure 3.

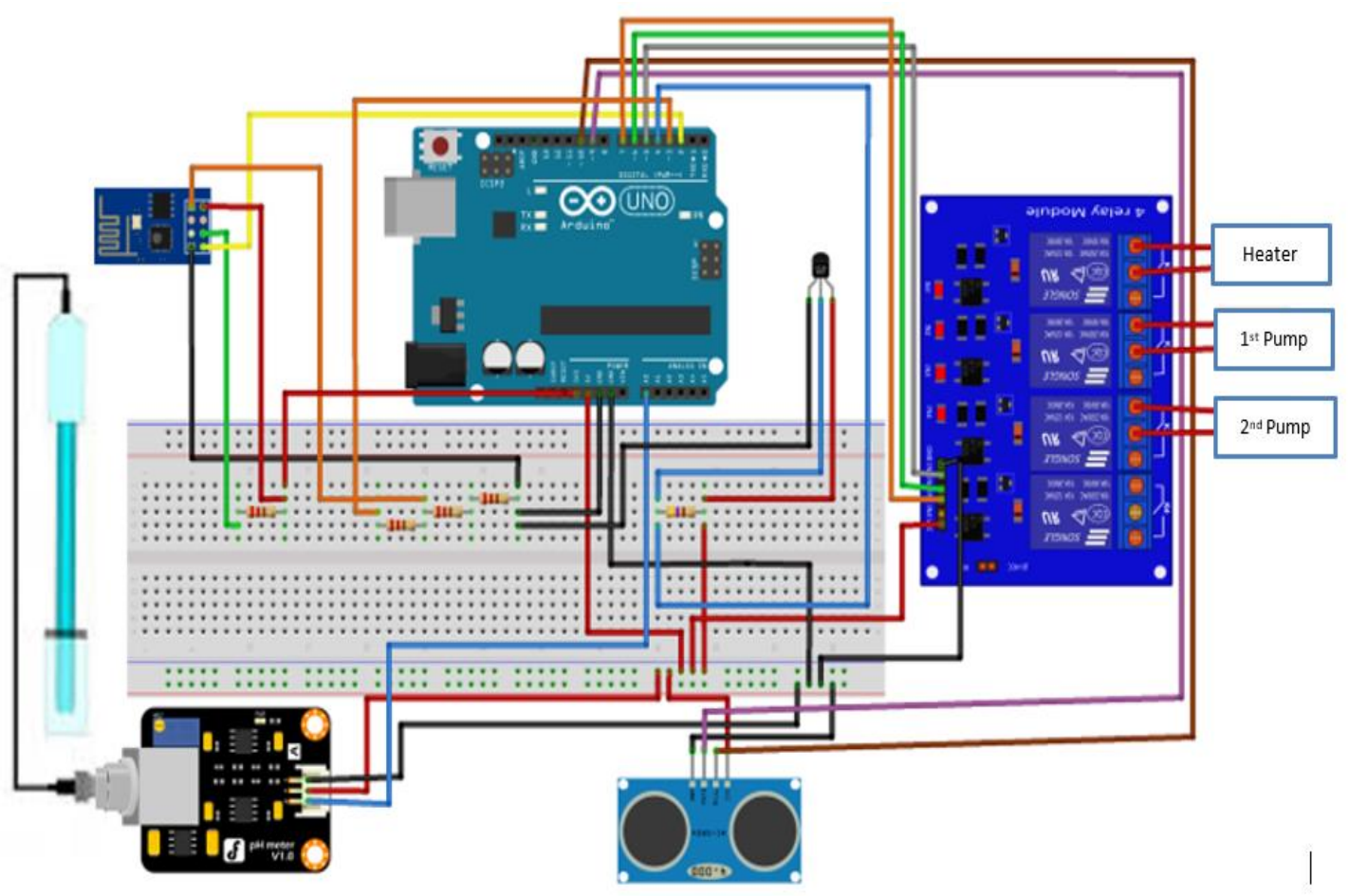

Figure 3. Device design

Fourth, software design. At this stage, mobile application design is carried out, including implanting the perceptron method into a mobile application, the Perceptron method is used because it produces input -1 , 0,1 , and one of the most famous prediction methods in artificial neural networks (ANN) [26], and has a high accuracy above 86\% [27]. One method of having a high success rate in the recognition system is that Perceptron is proven by research conducted by Thepade in 2018 in recognizing face gender with successful rate reaches $99.658 \%$ [28], also Mishra in 2015 in detecting automatic extraction of water bodies from landsat imagery [29]. 
One of the factors that influence the success of the recognition system is the accuracy of selecting threshold values. The threshold is the value used to adjust the weight value of the single layer perceptron. Besides, threshold value can be used to show the maximum accuracy from the variables that will be tested $[30,31]$. In this research, threshold value is used to test the parameter so that it can show a maximum water quality. The perceptron training algorithm is:

a. Initialize all weights and can determine the rate of understanding $(=\alpha)$. For simplification, usually $\alpha$ is given a value of 1 , where $\alpha$ is the learning rate specified, initialization of weights can use (1):

$$
w 1=b=0
$$

b. If there are input vector elements whose response unit output is not the same as the target, do:

i. Set the activation unit input where $S$ is the input vector with (2):

$$
X i=S i(i=1, \ldots, n)
$$

ii. Calculate the response unit output where ' $\mathrm{e}$ ' is the threshold specified by (3):

$$
\begin{aligned}
& \text { net }=\sum y i x i+b \\
& \text { net }=\sum y i x i+b \\
& y=\left\{\begin{array}{c}
1, \text { net }>\theta \\
0,-\theta \leq \text { net } \leq \theta \\
-1, \text { net }<-\theta
\end{array}\right.
\end{aligned}
$$

iii. Refine the pattern weights that contain errors $(y \neq t)$ where $t$ is the output target, according to (4), (5):

$$
\begin{aligned}
& W i(\text { new })=W i(\text { old })+\alpha t x i \\
& b(n e w)=b(\text { old })+\alpha t
\end{aligned}
$$

Before determining the suitability of water requirements, the first step is to determine the weight and bias values. This value of weight and bias will later determine whether the water condition is good or bad. Here is the (6):

$$
(X 1 . W 1)+(X 2 . W 2)+b
$$

where; $\mathrm{X}=$ =input value; $\mathrm{W}=$ weight; $\mathrm{b}=$ bias

After the weight and bias value can be obtained, the results will be used to determine water quality condition. The implementation is, if the result is equal to (-1) then the water condition is poor. Whereas if the result value is equal to (1), the water condition is good. This formula is placed on a mobile software, which work by processing input data from the sensor sent to the thingspeak server. In the application to be built there are five menus, namely the home menu, history menu, control menu and perceptron menu. The workings of the application in the temperature and $\mathrm{pH}$ control prototype on crayfish ponds are preceded by reading the data through the sensor by Arduino, which is then sent to the Thingspeak server. The data on the Thingspeak server is taken in the form of a json file which is then processed in the application.

The home menu displays the temperature, $\mathrm{pH}$ and the latest data updates that enter the Thingspeak server. The history menu displays a graph of the value of temperature, $\mathrm{pH}$ and water quality. The value of water quality in the calculation of temperature and $\mathrm{pH}$ using the perceptron method. On the control menu, there are heater control and manual water change display. Manual control can be done by pressing the on or off button. When the button is pressed, a data will be sent to the Thingspeak server and later the data will be read by Arduino to control the relay module. Whereas in the perceptron menu, display the perceptron calculation data based on the date order that the user wants. To make this application using an ionic framework and assisted with visual studio code for coding process.

Fifth is testing. Testing is done with two types of testing, the first test for temperature and $\mathrm{pH}$ sensors, where testing of these two sensors is done with four test scenarios, the first scenario, testing is done in an aquarium without including cfrayfish into the aquarium. The second scenario is testing the aquarium by inserting the crayfish into the aquarium. the first and second scenario tests did not use a temperature and $\mathrm{pH}$ control prototype tool that had been built in this study. The third and fourth scenarios are the same as the first 
and second tests but by implementing the tools that have been made. The second test was carried out on the accuracy of the perceptron method by utilizing 206 transaction data accuracy calculations using (7), where $\mathrm{AL}$ is the level of accuracy, while dy is the test data and $\mathrm{dx}$ is unrecognized test data.

$$
A L=\frac{d y-d x}{d y} \times 100 \%
$$

\section{RESULTS AND DISCUSSION}

The results of the device made by temperature and $\mathrm{pH}$ control prototypes on crayfish ponds have several supporting components that are connected to each other into the Arduino Uno as the control media of the operation of these devices. Figure 4 shows that is the overall appearance in the design of the prototype controlling temperature and $\mathrm{pH}$ on crayfish ponds. In this design, a sample of aquariums measuring $40 \mathrm{~cm} \mathrm{x}$ $25 \mathrm{~cm} \times 35 \mathrm{~cm}$ is used. For circuits packaged in such a way as in Figure 4. Where the circuit can be removed and installed in the desired aquarium.

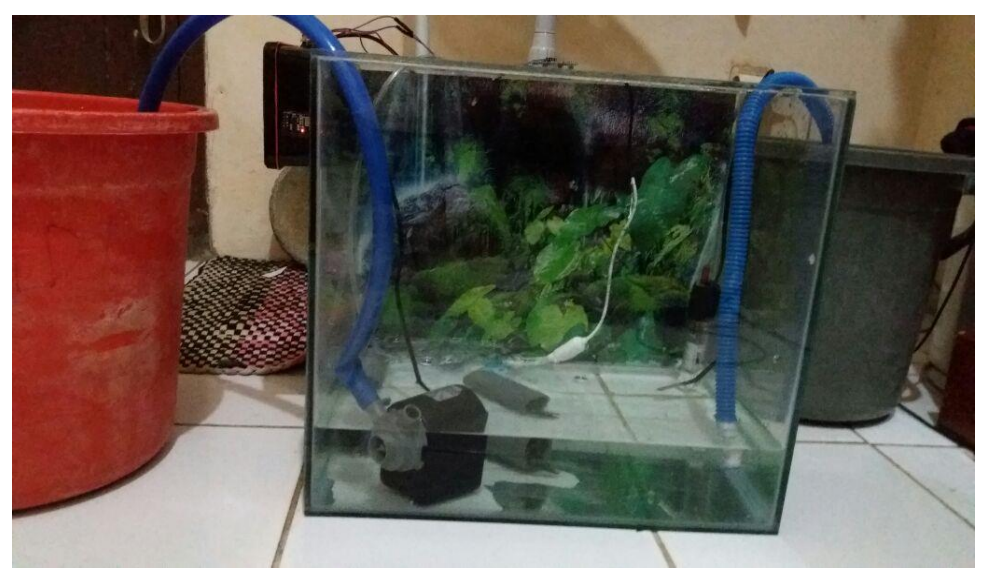

Figure 4. The overall tool design

In Figure 5 is a DS18B20 sensor and pH meter SKU: SEN0161. DS18B20 sensor is a sensor that serves to measure the temperature in water. While the $\mathrm{pH}$ meter SKU: SEN0161 is a sensor used to measure the $\mathrm{pH}$ of water. These two sensors will be inserted into the water so that it can monitor the quality of water in crayfish ponds. Determination of good or bad water quality is determined based on the results of the perceptron calculation. Figure 6. Shows the Arduino Uno series which then connected to the wifi module (can be seen on Figure 7.) which is used to get the internet connection so that the data can be sent to cloud and finally can be read by the user's Android mobile device.

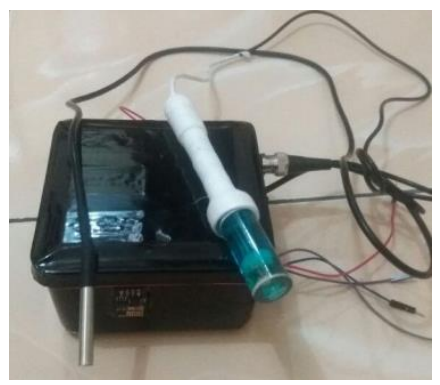

Figure 5. Display the temperature and $\mathrm{pH}$ sensor circuit pack

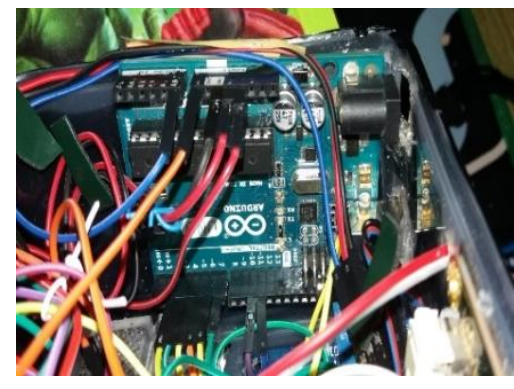

Figure 6. Display of the arduino uno circuit

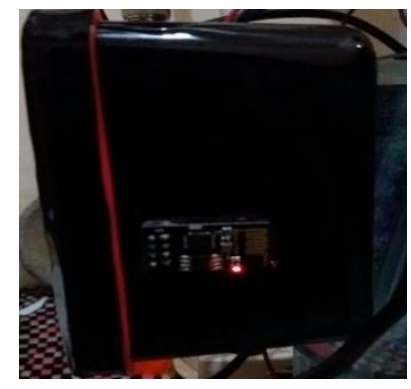

Figure 7. Display of the wifi module

Figure 8 is an ultrasonic sensor that functions to detect distance from objects in front of it. This sensor uses a sound system to determine the distance between the differences in front. For this reason, 
measuring the water in an aquarium is obtained from the aquarium which is input into the program minus the distance read by the ultrasonic sensor. Figure 9 is a picture of a 4 channel relay that serves to turn off or turn on a component connected to a relay. In the temperature and $\mathrm{pH}$ control prototype the crayfish pond uses only 3 channels of the existing 4 channels. The components connected to the relay are heaters and two water pumps.

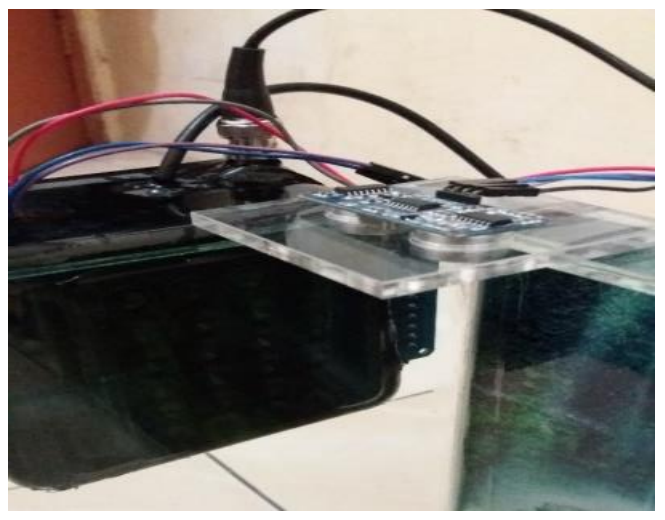

Figure 8. Untrasonic censor display

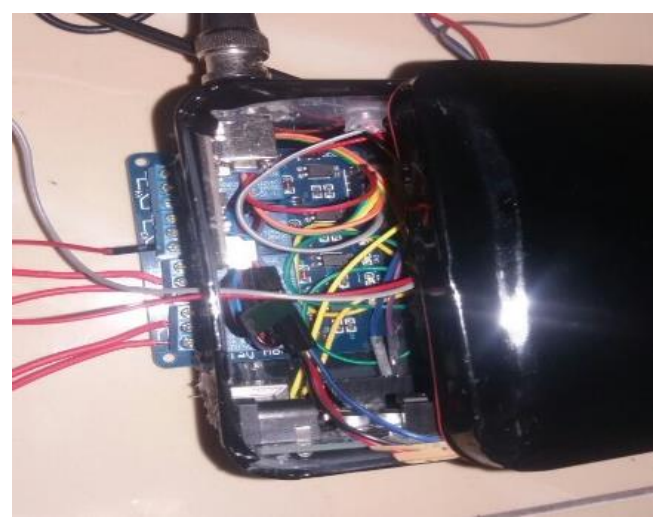

Figure 9. Relay-circuit display

After the next set of tools is made the stages of testing carried out on the sensor with four scenarios with the test results as shown in Figure 10. We can see at Figure 10, that the highest temperature was $30.13^{\circ} \mathrm{C}$ and the lowest temperature was $28.5^{\circ} \mathrm{C}$. As for $\mathrm{pH}$, the highest value is 12.89 and the lowest value is 6.88 . And for the average value of temperature and $\mathrm{pH}$ ranged from $29.32^{\circ} \mathrm{C}$ and $9.18 \mathrm{pH}$. In the graph, there is no decination in temperature beyond the optimal temperature limit because testing is carried out in closed spaces so that the room temperature affects the temperature in the aquarium.

The second test, which can be seen on Figure 11, shows that the highest temperature produced in this test was worth $30.5^{\circ} \mathrm{C}$ and the lowest temperature was $27.5^{\circ} \mathrm{C}$. While for the highest $\mathrm{pH}$ value is 7.82 and the lowest $\mathrm{pH}$ is 5.5 . For the average temperature and $\mathrm{pH}$, they were $29.80^{\circ} \mathrm{C}$ and $6.31 \mathrm{pH}$. In testing the second scenario, $\mathrm{pH}$ decreased from the second day to the third day, so that in this test, the crayfish were dead.

Based on previous experiments, the temperature reduction did not occur due to the influence of room temperature and weather conditions so that in the third experiment this was given stimulation in the form of cold water. When stimulated with cold water, the temperature obtained was $23.06^{\circ} \mathrm{C}$ so that the heater turned on. It can be seen in figure 12 there was a process of temperature rise which is affected by the heater.

In this test, monitoring has been built so that water quality is detected based on temperature and $\mathrm{pH}$ parameters. This system will replace water automatically if the detected value is -1 , which can be seen in figure 13 . From this test, the highest temperature is $28.88^{\circ} \mathrm{C}$ and the lowest temperature is $23.06^{\circ} \mathrm{C}$. Whereas for ph, the highest value is 8.08 and the lowest is 7 . For the average temperature and $\mathrm{pH}$ for the test times it is $27.50^{\circ} \mathrm{C}$ and $7.62 \mathrm{pH}$.

At this time, testing was carried out in a different room from the first to the third test so that the temperature obtained was more stable and did not need to be stimulated like the third test. In this test the writers got an obstacle in the internet network so that the data sent on the time server is inconsistent. Based on Figure 14 above, it is found that the highest temperature value is $29^{\circ} \mathrm{C}$ and the lowest is $24.75^{\circ} \mathrm{C}$. The highest $\mathrm{pH}$ is 8.25 and the lowest is 6.42 . For the average temperature and $\mathrm{pH}$ is $28.07^{\circ} \mathrm{C}$ and $7.03 \mathrm{pH}$. This test can be compared with the second test where the temperature and $\mathrm{pH}$ in the fourth test averaged at the optimal temperature and $\mathrm{pH}$. This happens because there is a process of controlling automation carried out by the microcontroller based on the value of water quality in Figure 15. 


\section{$1^{\text {st }}$ Scenario Test Result}

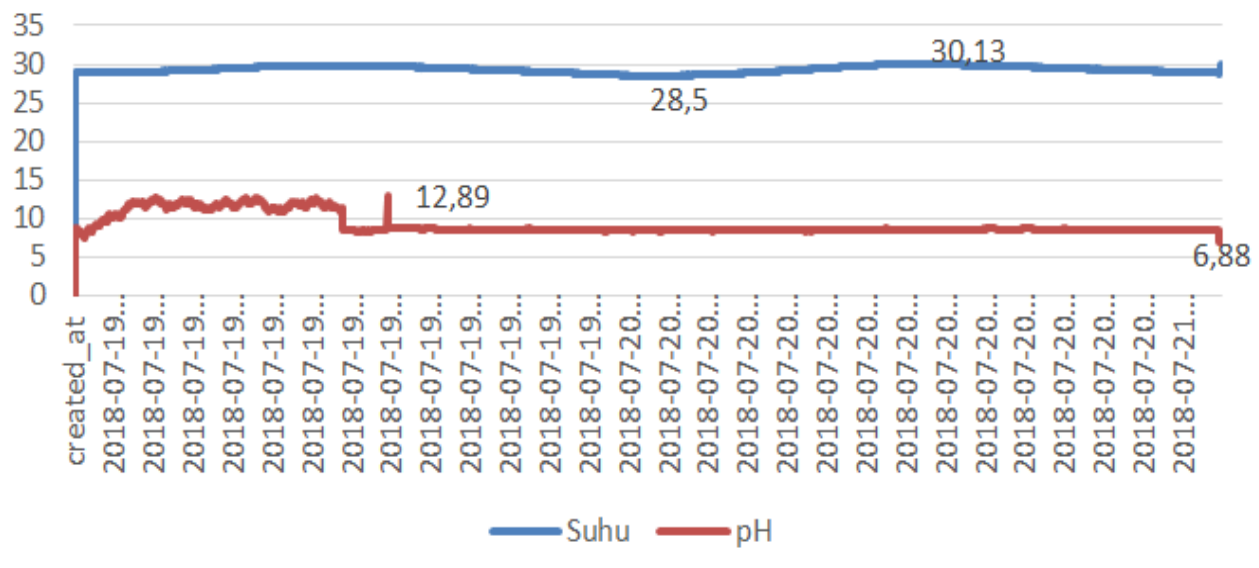

Figure 10. First scenario test result

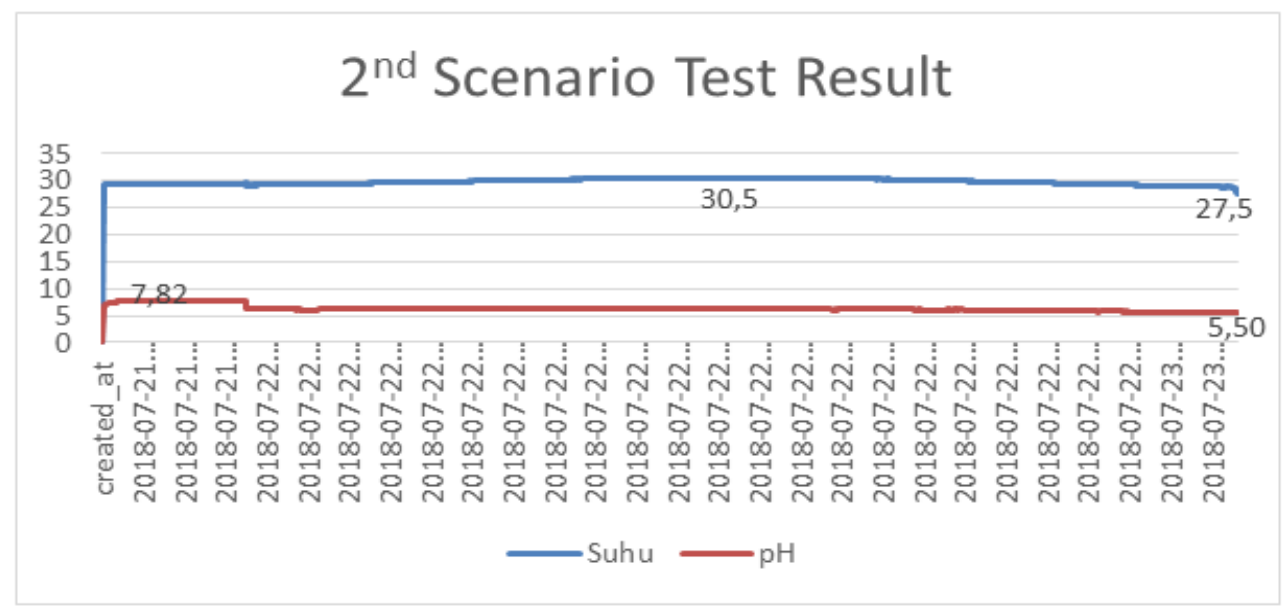

Figure 11. Second scenario test result

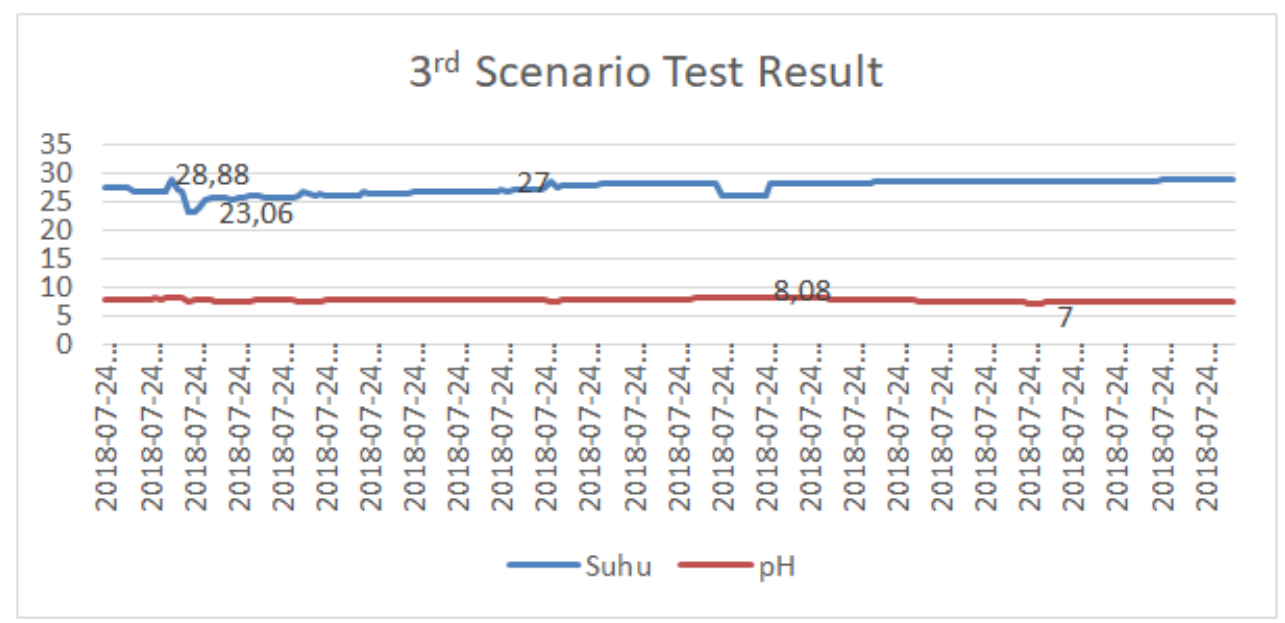

Figure 12. Third scenario test result 


\section{Water Quality Third Scenario Test Result}

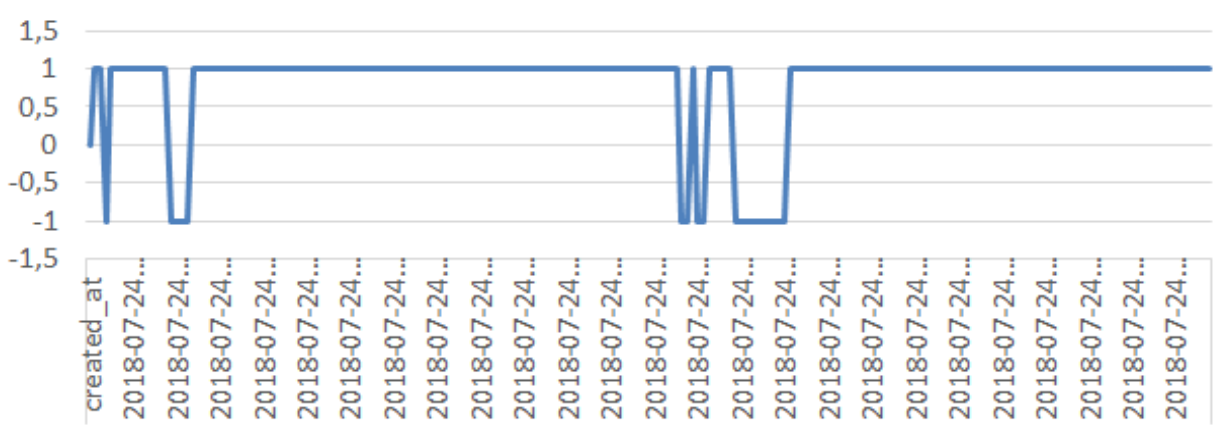

Figure 13. Water quality third scenario test result

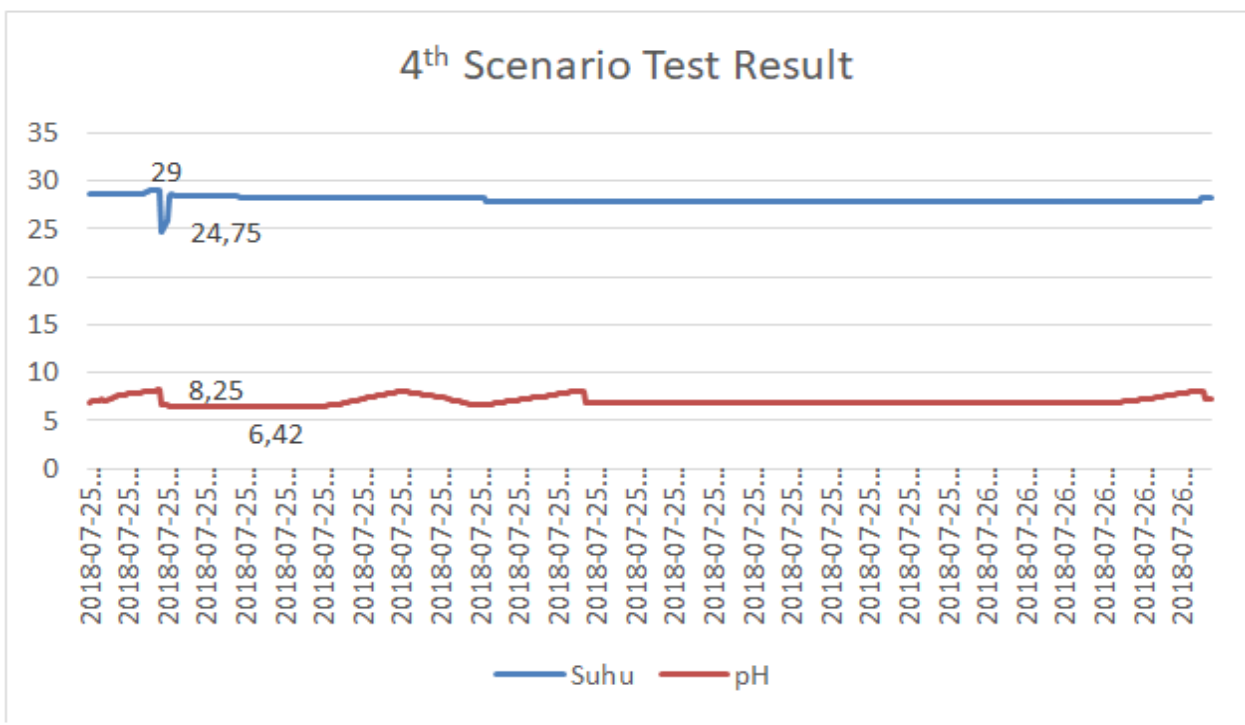

Figure 14. Fourth scenario test result

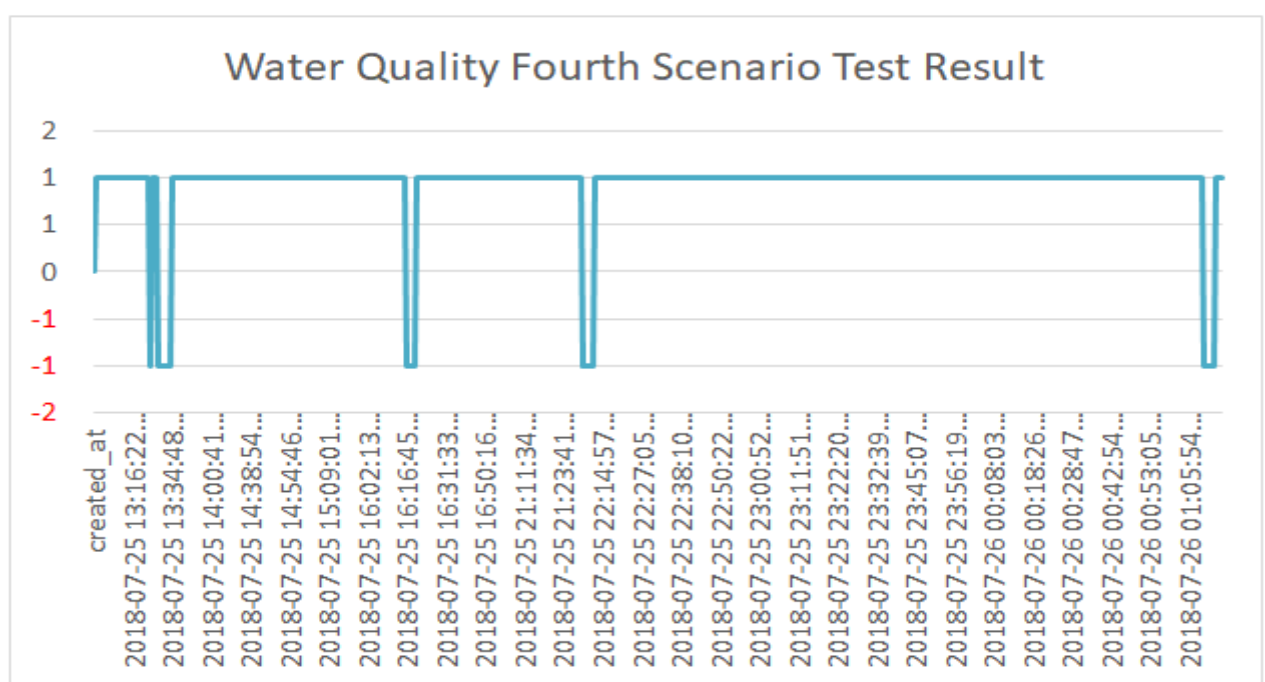

Figure 15. Water quality fourth scenario test result 
After testing the sensor, the next is the accuracy testing of the perceptron method, using the calculation of the $7^{\text {th }}$ formula, the results are:

$$
\begin{aligned}
A L & =\frac{206-4}{206} \times 100 \% \\
& =98,06 \%
\end{aligned}
$$

The level of accuracy obtained from calculations using the perceptron method shows good results, meaning that the perceptron method can be used to help show the quality of crayfish pond. Although the perceptron method has been successfully implemented in the lobster pond's water quality measurement with the high accuration level, but there are some problems on the mobile aplication; the processing speed depends on the smartphone's resources quality, on the perceptron training level up until the results of stabil weight and bias patterns will need a bigger smartphone's resources. It is better that the perceptron's training process is done at the server so that it will not burden the end users in using their applications.

\section{CONCLUSION}

In designing the hardware, the devices used in temperature and $\mathrm{pH}$ control prototypes on crayfish pond are temperature and $\mathrm{pH}$ sensors as input parameters. Then it is processed by the Arduino system circuit, ESP8266 module and relay. In designing software in an Android-based application using an ionic framework. This application functions as an interface to see the value of temperature and $\mathrm{pH}$ on crayfish ponds and can control manually if desired, because the system has recognized the condition; if the temperature is below $25^{\circ} \mathrm{C}$, then it will automatically turn on the heater and turn off automatically when conditions are met, when the perceptron method shows that the water quality is poor so the pump will be active to replace the water in the pond to replace it with good quality water.

From the tests that have been conducted, the use of temperature and $\mathrm{pH}$ control prototypes in crayfish ponds is able to control the condition of the water to remain optimal. This can be seen by comparing the testing of two and testing four where in the second test the average value of temperature and $\mathrm{pH}$ is around $29.80^{\circ} \mathrm{C}$ and $6.31 \mathrm{pH}$, whereas in the fourth test it shown $28.07^{\circ} \mathrm{C}$ and $7.03 \mathrm{pH}$. The unique feature in this paper is not only using IoT Technology into aquaculture to detect it, but being able to automatically maintain water quality, especially in crayfish ponds, using the perceptron method in determining water quality. The quality was good shown in the third scenario testing that the accuracy value is based on 206 data entered was 98.06\%. In the next study, additional parameters are needed such as dissolved oxygen, ammonia, nitrite, carbon dioxide $\left(\mathrm{CO}_{2}\right)$ and turbidity of water, which can be included in the perceptron calculation, thus helping crayfish cultivators maintain their crayfish to help increasing the quantity and quality of their crayfish.

\section{ACKNOWLEDGEMENTS}

This research is funded by Institute of Research and Community Service Institute of Technology PLN.

\section{REFERENCES}

[1] I. BPS-Statistics, Statistical Yearbook of Indonesia 2019. Jakarta: BPS-Statistics Indonesia, 2019.

[2] D. M. Holdich, BIOLOGY OF FRESHWATER CRAYFISH. UK: Wiley-Blackwell, 2001.

[3] P. Fossat, J. B. Cazenave, P. De Deurwaerdère, J.-P. Delbecque, and D. Cattaert, "Anxiety-like behavior in crayfish is controlled by serotonin," Science (80-. )., vol. 344, no. 6189, pp. 1293-1297, 2014.

[4] F. Grandjean, J. Momon, and M. Bramard, "Biological water quality assessment of the white-clawed crayfish habitat based on macroinvertebrate communities: Usefulness for its conservation," BFPP - Bull. Fr. la Pech. la Prot. des Milieux Aquat., no. 370-371 SPEC. ISS., pp. 115-125, 2003.

[5] J. L. Larimer and A. H. Gold, "Responses of the crayfish, Procambarus simulans, to respiratory stress," Physiol. Biochem. Zool., vol. 34, no. 2, 1961.

[6] J. Patoka, L. Kalous, and O. Kopecký, "Imports of ornamental crayfish: The first decade from the Czech Republic's perspective,” Knowl. Manag. Aquat. Ecosyst., vol. 2015-Janua, no. 416, pp. 1-9, 2015.

[7] Y. Yonvitner et al., "Enigmatic hotspot of crayfish diversity at risk: Invasive potential of non-indigenous crayfish if introduced to New Guinea," Aquat. Conserv. Mar. Freshw. Ecosyst., vol. 30, no. 2, pp. 219-224, 2020.

[8] S. Jin et al., "Optimizing reproductive performance and embryonic development of red swamp crayfish Procambarus clarkii by manipulating water temperature," Aquaculture, vol. 510, no. January, pp. 32-42, 2019.

[9] D. Wu, Y. Huang, Q. Chen, Q. Jiang, Y. Li, and Y. Zhao, "Effects and transcriptional responses in the hepatopancreas of red claw crayfish Cherax quadricarinatus under cold stress," J. Therm. Biol., vol. 85, no. March, p. 102404, 2019.

[10] M. Jaklič and A. Vrezec, "The first tropical alien crayfish species in European waters: The redclaw Cherax 
quadricarinatus (Von Martens, 1868) (Decapoda, Parastacidae)," Crustaceana, vol. 84, no. 5-6, pp. 651-665, 2011.

[11] M. J. Foysal, R. Fotedar, C. Y. Tay, and S. K. Gupta, "Biological filters regulate water quality, modulate health status, immune indices and gut microbiota of freshwater crayfish, marron (Cherax cainii, Austin, 2002)," Chemosphere, vol. 247, p. 125821, 2020.

[12] M. D. Putra et al., "Procambarus clarkii (Girard, 1852) and crayfish plague as new threats for biodiversity in Indonesia," Aquat. Conserv. Mar. Freshw. Ecosyst., vol. 28, no. 6, pp. 1434-1440, 2018.

[13] A. Abdurrasyid, I. Indrianto, and R. Arianto, "Detection of immovable objects on visually impaired people walking aids," TELKOMNIKA (Telecommunication Comput. Electron. Control., vol. 17, no. 2, p. 580, 2018.

[14] I. Indrianto, M. N. I. Susanti, R. Arianto, and R. R. A. Siregar, "Embedded System Practicum Module for Increase Student Comprehension of Microcontroller," TELKOMNIKA (Telecommunication Comput. Electron. Control., vol. 16, no. 1, p. 53, 2018.

[15] I. Indrianto, M. N. I. Susanti, R. R. A. Siregar, P. P. J., and Y. Purwanto, "Smart taxi security system design with internet of things (IoT)," TELKOMNIKA (Telecommunication Comput. Electron. Control., vol. 17, no. 3, p. 1250, 2019.

[16] D. Hartanti, R. N. Aziza, and P. C. Siswipraptini, "Optimization of smart traffic lights to prevent traffic congestion using fuzzy logic," Telkomnika (Telecommunication Comput. Electron. Control., vol. 17, no. 1, pp. 320-327, 2019.

[17] R. B. Lukito and C. Lukito, "Development of IoT at hydroponic system using raspberry Pi," TELKOMNIKA (Telecommunication Comput. Electron. Control., vol. 17, no. 2, p. 897, 2018.

[18] A. J. Odey and L. Daoliang, "AquaMesh - Design and Implementation of Smart Wireless Mesh Sensor Networks for Aquaculture," Am. J. Networks Commun., vol. 2, no. 3, p. 81, 2013.

[19] H. L. Chen and X. Q. Liu, "A Novel Kind of Smart Monitoring System of Aquaculture," in International Conference on Electrical, Computer Engineering and Electronics, 2015, no. 2, pp. 369-372.

[20] V. Klllç, G. Alankus, N. Horzum, A. Y. Mutlu, A. Bayram, and M. E. Solmaz, "Single-Image-Referenced Colorimetric Water Quality Detection Using a Smartphone,” ACS Omega, vol. 3, no. 5, pp. 5531-5536, 2018.

[21] M. A. A. Aziz, M. F. Abas, M. K. A. Abu Bashri, N. M. Saad, and M. H. Ariff, "Evaluating IoT based passive water catchment monitoring system data acquisition and analysis," Bull. Electr. Eng. Informatics, vol. 8, no. 4, pp. 1373-1382, 2019.

[22] M. Niroobakhsh, "Prediction of water quality parameter in Jajrood River basin: Application of multi layer perceptron (MLP) perceptron and radial basis function networks of artificial neural networks (ANNs)," African $J$. Agric. Reseearch, vol. 7, no. 29, pp. 4131-4139, 2012.

[23] D. S. Thambavani and T. S. R. Uma Mageswari, "Modeling of irrigation water quality using multilayer perceptron back propagation neural network (MLBP-NN).," Int. J. ChemTech Res., vol. 6, no. 5, pp. 3053-3061, 2014.

[24] F. Muharemi, D. Logofătu, and F. Leon, "Machine learning approaches for anomaly detection of water quality on a real-world data set," J. Inf. Telecommun., vol. 3, no. 3, pp. 294-307, 2019.

[25] A. M. Langer, Guide to Software Development, 2nd ed. New York, NY, USA: Springer, 2016.

[26] A. Firdaus Zainal Abidin et al., "Adaboost-multilayer perceptron to predict the student's performance in software engineering," Bull. Electr. Eng. Informatics, vol. 8, no. 4, pp. 1556-1562, 2019.

[27] Sugiarti, Yuhandri, J. Na'am, D. Indra, and J. Santony, "An artificial neural network approach for detecting skin cancer," Telkomnika (Telecommunication Comput. Electron. Control., vol. 17, no. 2, pp. 788-793, 2019.

[28] S. D. Thepade and D. Abin, "Face Gender Recognition Using Multi Layer Perceptron with OTSU Segmentation," Proc. - 2018 4th Int. Conf. Comput. Commun. Control Autom. ICCUBEA 2018, pp. 1-5, 2018.

[29] K. Mishra and P. R. C. Prasad, "Automatic Extraction of Water Bodies from Landsat Imagery Using Perceptron Model,” J. Comput. Environ. Sci., vol. 2015, pp. 1-9, 2015.

[30] B. T. Pham, D. Tien Bui, I. Prakash, and M. B. Dholakia, "Hybrid integration of Multilayer Perceptron Neural Networks and machine learning ensembles for landslide susceptibility assessment at Himalayan area (India) using GIS," Catena, vol. 149, pp. 52-63, 2017.

[31] G. M. Makris, A. Pouliakis, C. Siristatidis, N. Margari, E. Terzakis, and N. Koureas, "Image Analysis and MultiLayer Perceptron Artificial Neural Networks for the Discrimination Between Benign and Malignant Endometrial Lesions," Diagn. Cytopathol., vol. 36, no. 4, pp. 245-251, 2017.

\section{BIOGRAPHIES OF AUTHORS}

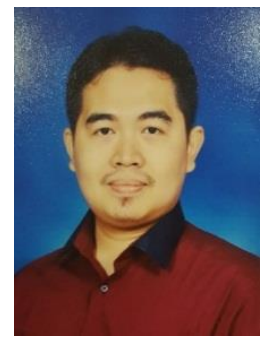

Abdurrasyid earned his magister degree at Bina Nusantara University in 2012. He currently is the Head of Informatics Engineering Study Program at Institut Teknologi PLN Jakarta. He has some technological appliances industrial experiences for more that 5 years. His research fields focus on embedded system and control and information system design. Up until today, he has already published many publications and copyrights in those fields. 


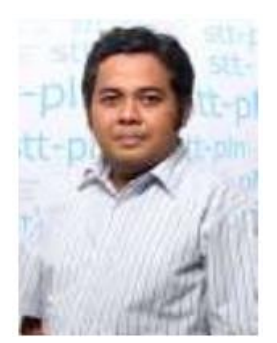

Indrianto, born in Jakarta. He completed Elementary School to High School in Jakarta and then continued his undergraduate study at STMIK Jakarta majoring in Computer Engineering until 1999 and then continued his Master degree in Gunadarma University and graduated in 2004. $\mathrm{He}$ is also active as a supervisor of practical work and thesis in the undergraduate program at ITPLN Jakarta. He also actively does some researches which in 2013 and 2014 received a novice lecturer grants from DIKTI, and from 2015 - 2018 received competitive grants for applied research, also from DIKTI. Presently, he is actively writing in some Scopus indexed journals. He wrote 8 Scopus indexed journals and 49 local and national journals in Informatics Engineering with h-index 2 and Google Scholar index 3. In addition to the above activities, the writer has also conducted computer application training for village officials for the West Jakarta area. Currently, he serves as the Head of the Institute for Research and Community Service at IT-PLN Jakarta.

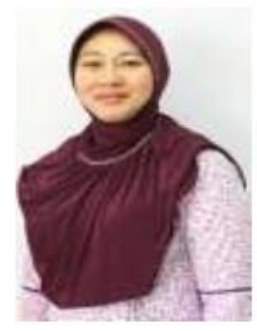

Meilia Nur Indah Susanti, was born in Jakarta. She finished her elementary school until high school in Jakarta and then continued his undergraduate study at Gunadarma University majoring in Information Engineering until 1998. She continued her magister study at the Indonesian Benarif College of Information Technology and graduated in 2005. In 1999, she began teaching at IT- PLN Jakarta and was appointed as a permanent lecturer at IT-PLN Jakarta in 2000. She is also active as a supervisor of practical work and thesis in the undergraduate program at the campus. She is also active on the website editorial board and the editorial board of the "PETIR" journal. She received novice lecturer grants from DIKTI in 2013 and 2014, and received competitive grants for applied research, also from DIKTI from 2015 - 2018. In that sense, she is also actively writing several journals for the editor and some Scopus indexed journals. She wrote 8 Scopus indexed journals and 34 local and national journals in Informatics Engineering with hindex 2 and Google Scholar index 4. In addition to the above activities, the writer has also conducted computer application training for village officials for the West Jakarta area. Currently, she serves as the Head of the Department of Informatics Engineering at IT-PLN Jakarta.

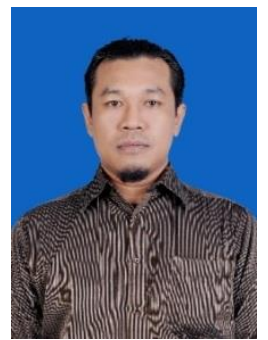

Yudhi S. Purwanto is a lecturer at IT-PLN Jakarta. He holds two magisters, i.e. in Management and Linguistics. Apart from his daily teaching activities, he loves to try new things and exploring new skills and knowledge. He believes that a knowledgeable and skillful lecturer will give a great impact to the development of the students. Currently, he actively makes some research related to his fields, and also establish some join research with his fellow lecturers from some other fields, especially from Informatics. 